\title{
Koroze konstrukčních materiálů působením kyseliny borité
}

\section{The corrosion of construction materials induced by boric acid}

\author{
Kobzová A. ${ }^{1}$, Kárník D. ${ }^{1}$, Skoumalová Z. ${ }^{1}$, Marcinský P. ${ }^{2}$ \\ ${ }^{1}$ ÚJV Řež, a.s. \\ 2 JE Mochovce \\ E-mail: alena.kobzova@ujv.cz
}

V provozních podmínkách primárního okruhu jaderných elektráren nelze vyloučit kontakt primárního média s obsahem kyseliny borité s konstrukčními kovovými materiály. Obsahem experimentálni práce bylo simulovat vybrané varianty expozice konstrukčních materiálù primárnímu médiu a kvantifikovat jeho korozni účinky. Základními faktory ovlivňujicimi korozi byly teplota povrchu materiálu, koncentrace kyseliny borité a možnost odvodu vodni páry od povrchu. Vrstva páry se tvoři při vysoké teplotě a chráni povrch před kontaktem s kyselinou boritou a bráni koroznimu poškozeni. Odpařování kyseliny borité závisi také na množství vody (koncentraci kyseliny borité). Přebytek vody umožňuje destilaci kyseliny borité a prebytek kyseliny borité má za následek vznik neškodné sklovité vrstvy $z$ taveniny kyseliny borité.

\section{ÚVOD}

VVER typ reaktoru je ruskou verzí PWR reaktorů. Oba typy reaktoru používají kyselinu boritou k moderování toku neutronů v primárním okruhu, a která $\mathrm{v}$ př́padě úniku může způsobit korozi konstrukčních materiálů. Korozní rychlosti konstrukčních ocelí nejsou př́liš vysoké, ale zvýšená teplota hraje významnou roli [1]. Jiným efektem zvyšujícím korozní rychlost je vyvěrání, které má za následek rychlý úbytek materiálu. Je nutné brát $\mathrm{v}$ úvahu vhodné hodnocení chemie, materiálové složení a mechanické vlastnosti materiálu. Je mnoho prací shrnující tyto poznatky pro materiály používané pro PWR reaktory, ale pro materiály užité pro VVER reaktory stále chybí. Zevrubný přehled korozních rychlostí za statických podmínek byl již publikován [2], ale za podmínek zahrnující dynamické působení bylo publikováno jen minimum informací.

Z chemického úhlu pohledu je kyselina boritá velmi slabou kyselinou, jež velmi neochotně odštěpuje proton $(\mathrm{pKa}=9.25)$ [3] a to tak, že se molekula $\mathrm{H}_{3} \mathrm{BO}_{3}$ hydratuje dvěma molekulami vody a odštěpí proton za vzniku

tetrahydroxoboritanového aniontu [4]. Z toho plyne, že pro uplatnění kyselých vlastností kyseliny borité je nutná přítomnost vody.

Za zvýšených teplot (nad $\left.100^{\circ} \mathrm{C}[5]\right)$ kyselina boritá $\left(\mathrm{H}_{3} \mathrm{BO}_{3}\right)$ odštěpuje vodu za vzniku kyseliny monohydrogenborité (metaboritá, $\mathrm{HBO}_{2}$ ), jejíž chemické chování se od $\mathrm{H}_{3} \mathrm{BO}_{3}$ takřka neliší. Kyselina monohydrogenboritá okamžitě kondenzuje na cyklickou strukturu $\mathrm{H}_{3} \mathrm{~B}_{3} \mathrm{O}_{6}$ [4]. Při dalším zvýšení teploty na $450{ }^{\circ} \mathrm{C}$ vzniká oxid boritý [4], který má polymerní charakter a je málo těkavý. Při teplotách mezi 104 a $200{ }^{\circ} \mathrm{C}$ jsou kyseliny boritá $\left(\mathrm{H}_{3} \mathrm{BO}_{3}\right)$ i metaboritá $\left(\mathrm{HBO}_{2}\right) \mathrm{v}$ př́tomnosti vody značně těkavé. Těkavost kyseliny borité za př́tomnosti vody respektive v parním prostředí je popsána distribučním koeficientem [6], který je při $230{ }^{\circ} \mathrm{C} 0.049$, pro $265^{\circ} \mathrm{C}$ je 0.070 a pro $297^{\circ} \mathrm{C}$ dosahuje hodnoty 0.112 . Při poslední teplotě je tedy hmotnostní koncentrace kyseliny borité v parní fázi $11.2 \%$, což při neustálém toku čerstvé páry znamená, že se roztok kyseliny borité odpařuje. V závislosti na konkrétním uspořádání a podmínkách proudění vzduchu může docházet ke zpětné kondenzaci roztoku kyseliny na chladnějších částech zařízení. 
Cílem práce bylo:

a) Stanovit hodnotu korozní rychlosti konstrukčních ocelí v prostředí roztoků kyseliny borité při teplotě $297^{\circ} \mathrm{C}$.

b) Stanovit hodnotu korozní rychlosti konstrukčních ocelí při kontaktu zahřátých povrchů s kapalným médiem s obsahem kyseliny borité.

c) Stanovit hodnotu korozní rychlosti konstrukčních ocelí s povrchem kontaminovaným kyselinou boritou včetně návrhu opatření, která je nutné realizovat při kontaminaci kovových povrchů.

\section{EXPERIMENTÁLNÍ ČÁST}

\section{Zkušební vzorky}

Pro experimentální práce byly zadavatelem určeny tři typy $\mathrm{v}$ provozu často využívaných konstrukčních ocelí pro VVER 440/213:

08Ch18N10T

Korozivzdorná austenitická ocel

15Ch2MFA

Bainitická ocel

$22 \mathrm{~K}$

Uhlíková ocel

Vzorky materiálů určených $\mathrm{k}$ experimentům byly podrobeny chemické analýze metodou optické emisní spektrometrie (OES) prostřednictvím mobilního analyzátoru ARCMET MobileLab SP (výrobce Oxford Instruments). Výsledky analýz jsou souhrnně uvedeny v Tab. 1 .

Z materiálů byly následně vyrobeny sady zkušebních plochých korozních vzorků o rozměrech $15 \times 60 \times 1 \mathrm{~mm}$ (po 8 vzorcích z každého materiálu) a $30 \times 60 \times 1 \mathrm{~mm}$ (po 6 vzorcích z každého materiálu).

Vzorky byly z důvodu následných gravimetrických hodnocení zváženy.

\section{Statická část zkoušek - expoziční zkouška v roztoku kyseliny borité}

Pro korozní zkoušky $\mathrm{v}$ roztocích kyseliny borité byla zvolena varianta expozice plochých korozních vzorků rozměru $15 \times 60 \times 1 \mathrm{~mm}$ po dobu 1000 hodin na teplotě $297.0 \pm 0.5^{\circ} \mathrm{C}$ s následným gravimetrickým hodnocením korozních úbytků.

Jako korozní prostředí byly zvoleny dva následující roztoky kyseliny borité:

Prostředí A: $14 \mathrm{~g} / \mathrm{kg} \mathrm{H}_{3} \mathrm{BO}_{3} \mathrm{v}$ demineralizované vodě

Prostředí B: $5 \mathrm{~g} / \mathrm{kg} \mathrm{H}_{3} \mathrm{BO}_{3}+\mathrm{KOH}$ na $\mathrm{pH}_{(300)} 7.2$ v demineralizované vodě

Pro expozici vzorků byly vyrobeny dvě korozní ampule s devíti místy na vzorky (schéma na Obr. 1).

\section{Dynamická část zkoušek - zkoušky periodického vlhčení a kontaminace}

Pro ohřev plochých korozních vzorků byla použita měděná temperovaná plotna se zabroušeným povrchem pro zlepšení přestupu tepla do materiálu vzorku. Na tomto zařízení byla provedena následující řada experimentů. Každý experiment byl opakován třikrát.

Prvním byla zkouška korozní odolnosti materiálů při periodickém smáčení povrchu kovu roztokem kyseliny borité (I). Tento základní test byl proveden na všech vybraných typech materiálů a za všech vybraných teplot. Dávkování korozního prostředí $\mathrm{B}$ bylo realizováno peristaltickým mikročerpadlem a odkapávání média bylo z konstantní výšky 20 mm přes kovovou kapiláru. Průtok korozního média byl po dobu experimentu konstantní na úrovni $10 \mathrm{ml} /$ hodinu po dobu 150 hodin.

Druhým typem experimentu (II) byla zkouška korozní odolnosti materiálů při kontaminaci povrchů kyselinou boritou na úrovni $10 \mathrm{mg} \mathrm{H}_{3} \mathrm{BO}_{3} / \mathrm{cm}^{2} \mathrm{v}$ suchém

Tab. 1. Složení materiálu experimentálních vzorků / Chemical composition of samples

\begin{tabular}{|c|c|c|c|c|c|c|}
\hline \multirow{2}{*}{ Prvek } & \multicolumn{6}{|c|}{ Ocel } \\
\cline { 2 - 7 } & \multicolumn{2}{|c|}{ 08Ch18N10T } & \multicolumn{2}{c|}{ 15Ch2MFA } & \multicolumn{2}{c|}{ 22K } \\
\cline { 2 - 7 } & Norma & Analýza & Norma & Analýza & Norma & Analýza \\
\hline $\mathrm{C}$ & max. 0,08 & 0,076 & 0,18 & 0,165 & $0,19-0,26$ & 0,237 \\
\hline $\mathrm{Si}$ & max. 1,00 & 0,438 & 0,31 & 0,145 & $0,2-0,4$ & 0,235 \\
\hline $\mathrm{Mn}$ & max. 2,00 & 1,129 & 0,50 & 0,322 & $0,75-1,00$ & 0,811 \\
\hline $\mathrm{Cr}$ & $17,0-19,0$ & 19,42 & 2,80 & 2,779 & max. 0,4 & 0,244 \\
\hline $\mathrm{Ni}$ & $9,5-12,0$ & 9,61 & 0,07 & 0,135 & max. 0,3 & 0,379 \\
\hline $\mathrm{S}$ & - & 0,014 & 0,016 & 0,011 & max. 0,025 & 0,007 \\
\hline $\mathrm{P}$ & - & 0,019 & 0,014 & 0,023 & max. 0,025 & 0,021 \\
\hline $\mathrm{Cu}$ & - & 0,046 & 0,10 & 0,078 & max. 0,3 & 0,056 \\
\hline $\mathrm{Ti}$ & min. $5 \times \mathrm{C}$ & 0,457 & - & - & & - \\
\hline
\end{tabular}


prostředí. Tento typ testu byl proveden na všech vybraných typech materiálů za vybrané teploty. Na vzorcích byla vymezena kruhová oblast, na které byla modelována požadovaná kontaminace vyloučením kyseliny borité z etanolového roztoku. Takto kontaminované vzorky byly exponovány na požadované teplotě.

Třetí typ experimentu (III) byla zkouška korozní odolnosti při kontaktu povrchu materiálu s krystalickou kys. boritou $\mathrm{v}$ prostředí $\mathrm{s}$ přítomností vodních par. Vzorky byly připraveny stejným postupem jako pro experiment II, jen zahřívání na požadovanou teplotu bylo provedeno $\mathrm{v}$ uzavřeném boxu, do kterého bylo parní prostředí generováno kapáním demineralizované vody na odpařovací plochu mimo samotný exponovaný vzorek.

Čtvrtý typ experimentu (IV) představoval korozní test, kdy materiál je v kontaktu s vysokým množstvím suché kys. borité. Krystalická kyselina boritá o množství 0,1 g byla umístěna na vzorek, který byl následně zahřát po dobu 150 hodin.

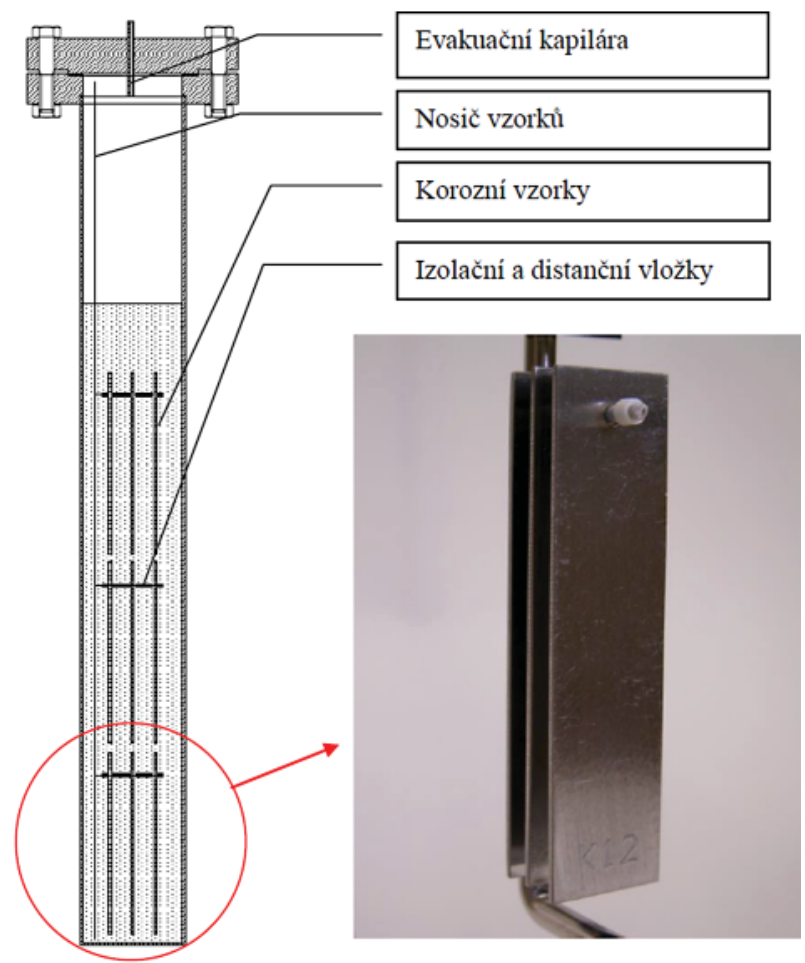

Obr. 1. Ampule pro expoziční korozní zkoušku Fig. 1. The capsule for autoclave test
Poslední pátý typ experimentu (V) byl stejný jako typ IV, jen proběhl v boxu jako test III.

Souhrn všech experimentů je uveden v následující Tab. 2.

\section{Výpočet korozní rychlosti}

Metodou gravimetrických měření byla vypočtena rychlost rovnoměrné koroze a na optickém mikroskopu indikována korozní poškození. Pro jeho detailní popis byla u vybraných vzorků provedena metalografická analýza v místě poškození, orientovaná na určení největší hloubky korozního poškození. Hodnota největší hloubky korozního poškození byla použita pro výpočet korozní rychlosti.

\section{VÝSLEDKY}

\section{Statická část zkoušek}

Ve všech prŕípadech byla po expozici zjištěna na povrchu vzorků kompaktní oxidická vrstva bez přítomnosti viditelných nehomogenit. Vrstva měla velmi dobrou prrilnavost $\mathrm{k}$ povrchu. Moření povrchu vzorků před gravimetrickým stanovením korozních úbytků bylo provedeno dle normy ČSN ISO 8407, samotný výpočet korozní rychlosti podle normy ČSN 038104. Výsledky gravimetrického hodnocení korozní rychlosti jednotlivých materiálů $\mathrm{v}$ expozičním testu jsou uvedeny v Tab. 3.

Tab. 3. Výsledky gravimetrického hodnocení koroze / Gravimentric evaluation of static exposition test

\begin{tabular}{|c|c|c|}
\hline \multirow{2}{*}{ Materiál } & Prostředí & $\begin{array}{c}\text { Korozní rychlost* } \\
\text { [mm/rok] }\end{array}$ \\
\hline \multirow{2}{*}{ 15Ch2MFA } & $\mathrm{A}$ & $0.0078 \pm 0.0002$ \\
\cline { 2 - 3 } & $\mathrm{B}$ & $0.0083 \pm 0.0015$ \\
\hline \multirow{2}{*}{$22 \mathrm{~K}$} & $\mathrm{~A}$ & $0.0047 \pm 0.0002$ \\
\cline { 2 - 3 } & $\mathrm{B}$ & $0.0046 \pm 0.0001$ \\
\hline \multirow{2}{*}{$08 \mathrm{Ch} 18 \mathrm{~N} 10 \mathrm{~T}$} & $\mathrm{~A}$ & $0.0011 \pm 0.0001$ \\
\cline { 2 - 3 } & $\mathrm{B}$ & $0.0019 \pm 0.0007$ \\
\hline
\end{tabular}

*) smérodatná odchylka je stanovena z měreni tři vzorků

Tab. 2. Souhrn provedených dynamických experimentů / Summary of dynamic exposition tests

\begin{tabular}{|c|c|c|c|c|}
\hline \multirow{2}{*}{ Materiál } & \multicolumn{4}{|c|}{ Teplota / typy testů } \\
\cline { 2 - 5 } & $\mathbf{2 9 7}^{\circ} \mathbf{C}$ & $\mathbf{2 6 5}^{\circ} \mathbf{C}$ & $\mathbf{2 3 0}^{\circ} \mathbf{C}$ & $\mathbf{1 6 0}^{\circ} \mathbf{C}$ \\
\hline 08 Ch18N10T & I. & I., II., III., IV., V. & I. & I. \\
\hline $22 \mathrm{~K}$ & I. & I. & I., II., III., IV., V. & I. \\
\hline 15 Ch2MFA & I. & I. & I., II., III., IV., V. & I. \\
\hline
\end{tabular}




\section{Dynamická část zkoušek - zkoušky periodického vlhčení a kontaminace}

Podle očekávání bylo potvrzeno, že korozní účinky periodického smáčení povrchu závisí v rozhodující míře na teplotě povrchu kovu.

Při teplotách vzorku do přibližně $150^{\circ} \mathrm{C}$ docházelo $\mathrm{k}$ relativně pomalému odpařování roztoku a trvalému zvlhčení povrchu. Tento interval teplot nebyl cílem práce a nebyl dále studován.

Při zvýšení teploty nad $150{ }^{\circ} \mathrm{C}$ docházelo $\mathrm{k}$ relativně rychlému odpaření vody, ale teplotní závislost rozdělovacího koeficientu kyseliny borité neumožnila úplné odpaření kyseliny borité s vodní párou. $\mathrm{Z}$ tohoto

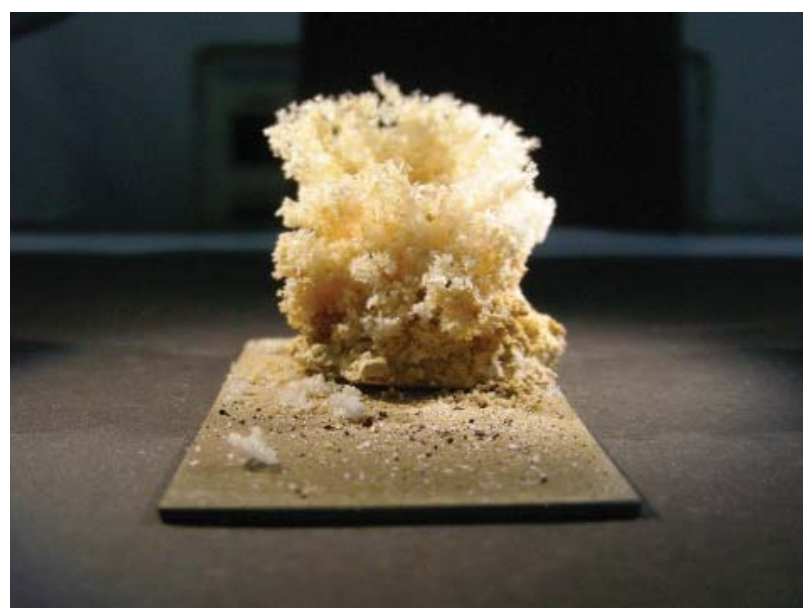

Obr. 2. Vzhled vrstvy krystalů kyseliny borité na vzorku po testu I. prí $160^{\circ} \mathrm{C}$ (materiál 15Ch2MFA, 150 hodin, rychlost kapání $10 \mathrm{ml} / \mathrm{hod}$ )

Fig. 2. The crystals of boric acid on the surface of mild steel (15Kh2MFA, 150 hours, $160^{\circ} \mathrm{C}, 10 \mathrm{ml} / \mathrm{h}$ ) důvodu vznikla na povrchu vzorku vrstva jemných krystalů kyseliny borité, jejíž charakteristická okrová barva byla způsobena korozními produkty materiálu vzorku (Obr. 2). Na všech vzorcích byl pozorován výkvět krystalů kyseliny borité v okolí dopadu kapky korozního prostředí. Po odstranění krystalů bylo patrné výrazné lokální korozní poškození v případě vzorků materiálu 22K a 15Ch2MFA (Obr. 3). Metalografická analýza potvrdila poškození povrchu uvedených materiálů (Obr. 4).

Při zvýšení teploty nad přibližně $230^{\circ} \mathrm{C}$ se dopadající kapka korozního roztoku nad povrchem vzorku vznáší na parním polštáŕi bez přímého kontaktu korozního prostředí s materiálem vzorku. Za těchto podmínek dochází k úplnému odpaření použitého korozního roztoku ve vznosu a povrch vzorku je bez zjistitelného korozního poškození. Kapka kyseliny borité není v př́mém kontaktu s povrchem materiálu. Hmotnostní úbytky jsou nižší než u vzorků exponovaných při nižší teplotě $160{ }^{\circ} \mathrm{C}$. Metalografické hodnocení povrchu je na Obr. 5 .

Vliv zbytkové povrchové kontaminace kyselinou boritou na korozi vzorku byl zjišt'ován pro úroveň $10 \mathrm{mg} / \mathrm{cm}^{2}$ kyseliny borité. Zkouška teplotní expozice kontaminovaných vzorků byla provedena jak ve standardním prostředí laboratoře, tak v prostředí za zvýšené přítomnosti vodní páry $\mathrm{v}$ atmosféře. Přítomnost vodní páry $\mathrm{v}$ atmosféře má za následek postupné odpaření kyseliny borité s vodní parou a tedy faktickou dekontaminaci povrchu. Pro komplexnost hodnocení byl proveden shodný experiment i s masívní kontaminací kyselinou boritou formou zásypu povrchu vzorku $0.1 \mathrm{~g}$ krystalické kyseliny borité.

Povrch vzorků v oblasti kontaminace $\mathrm{i}$ mimo ni po typu zkoušky II, III (kys. boritá na úrovni $10 \mathrm{mg}$ $\mathrm{H}_{3} \mathrm{BO}_{3} / \mathrm{cm}^{2} \mathrm{v}$ suchém prostředí a s prítomností vodních
22K

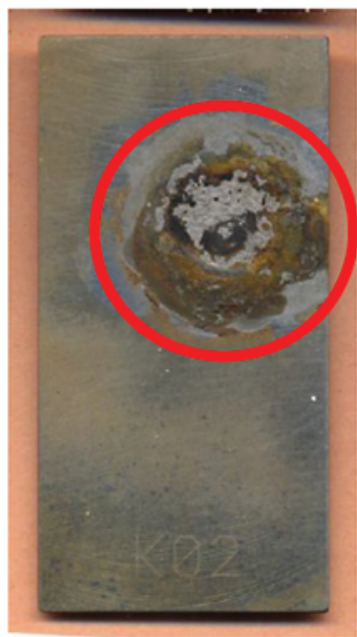

Korozní úbytek : $0.13289 \mathrm{~g}$
15Ch2MFA

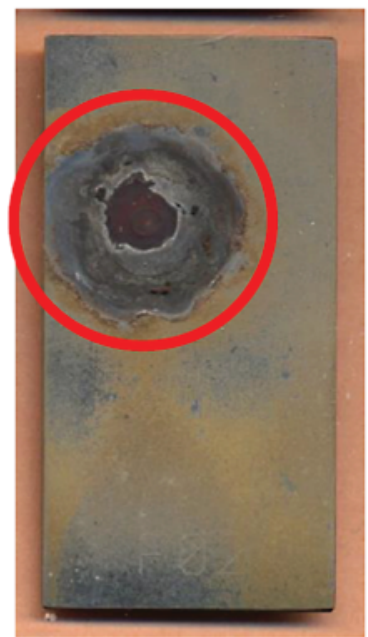

Korozní úbytek : $0.05502 \mathrm{~g}$

\section{Ch18N10T}

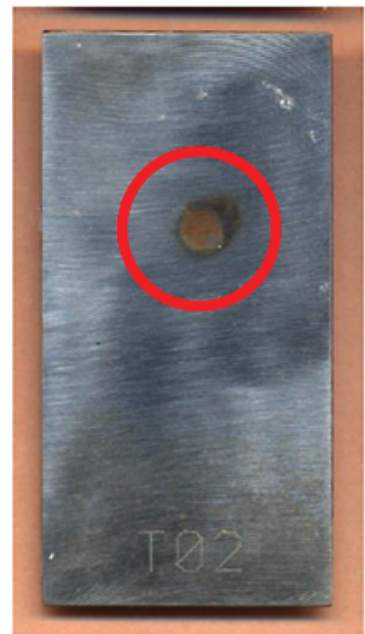

Korozní úbytek : $<0.0005 \mathrm{~g}$

Obr. 3. Vzorky po expozici varianta I., teplota $160^{\circ} \mathrm{C}$

Fig. 3. Samples after exposition (test $l, 160^{\circ} \mathrm{C}$ ) 
par) nevykazoval zjistitelné rozdíly. Povrch vzorku byl beze stop koroze.

Po zkoušce s krystalickou kys. boritou v suchém prostředí (typ IV) byl povrch kontaminovaný krystalickou kyselinou boritou pokryt vrstvou bílé průsvitné taveniny kyseliny metaborité, po jejím odstranění zůstal povrch vzorku pod vrstvou lesklý bez pokryvu vrstvou oxidů.

Po zkoušce s krystalickou kys. boritou v prostředí $\mathrm{s}$ přítomností vodních par (typ V) nebyla prrítomna kyselina metaboritá - vlivem parního prostředí došlo k jejímu odpaření. Povrch vzorku nebyl korozně poškozen, pouze charakter oxidické vrstvy v místě původní vrstvy kyseliny borité se mírně lišil od okolního povrchu vzorku.

Vzorky po expozicích při $265^{\circ} \mathrm{C}$ pro všechny typy zkoušek nevykazovaly žádné stopy korozního napadení. $\mathrm{Na}$ povrchu vzorku byly jen nezřetelné stopy lokality dopadu kapky - kontakt povrchu vzorku s korozním médiem byl eliminován vzniklým parním polštářem.

Po zkoušce korozní odolnosti při kontaktu povrchu materiálu s krystalickou $\mathrm{H}_{3} \mathrm{BO}_{3} \mathrm{v}$ suchém prostredí byla patrná vrstva taveniny kyseliny metaborité, po jejím následném odstranění nebyly zjištěny stopy koroze. Patrná

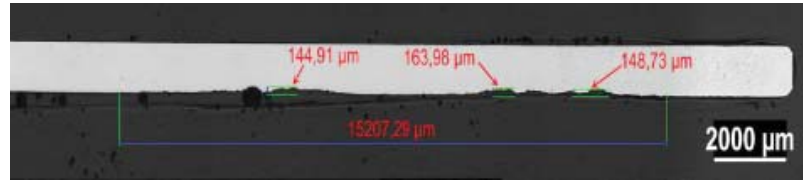

a) $22 \mathrm{~K}$

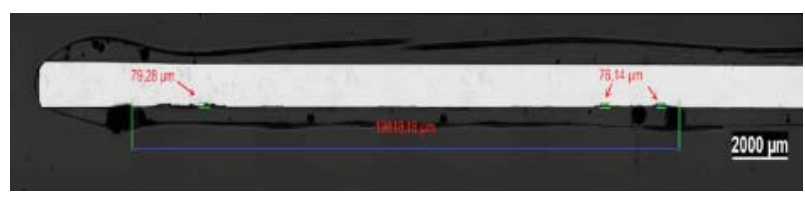

b) 15Ch2MFA

Obr. 4. Příčný řez exponovaným vzorkem materiálu 22K (a) a 15Ch2MFA (b) s uvedenými hloubkami korozního poškození při teplotě $160^{\circ} \mathrm{C}$

Fig. 4. Sample cut of $22 \mathrm{~K}$ (a) and $15 \mathrm{Ch} 2 \mathrm{MFA}$ (b) at $160^{\circ} \mathrm{C}$

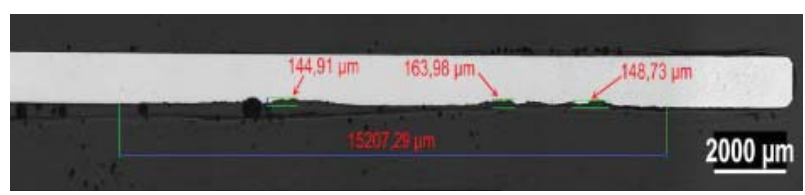

a) $22 \mathrm{~K}$

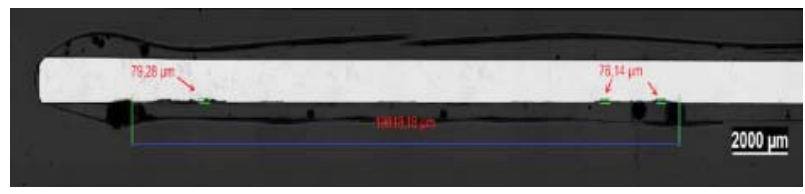

b) 15Ch2MFA

Obr. 5. Příčný řez exponovaným vzorkem materiálu 22K (a) a 15Ch2MFA (b) s uvedenými hloubkami korozního poškození při teplotě $230^{\circ} \mathrm{C}$

Fig. 5. Sample cut of $22 \mathrm{~K}$ (a) and $15 \mathrm{Ch} 2 \mathrm{MFA}$ (b) at $230^{\circ} \mathrm{C}$ je pouze absence oxidické vrstvy (změna zbarvení vzorku v místě př́itomnosti kyseliny metaborité - Obr. 6).

\section{Ch18N10T}

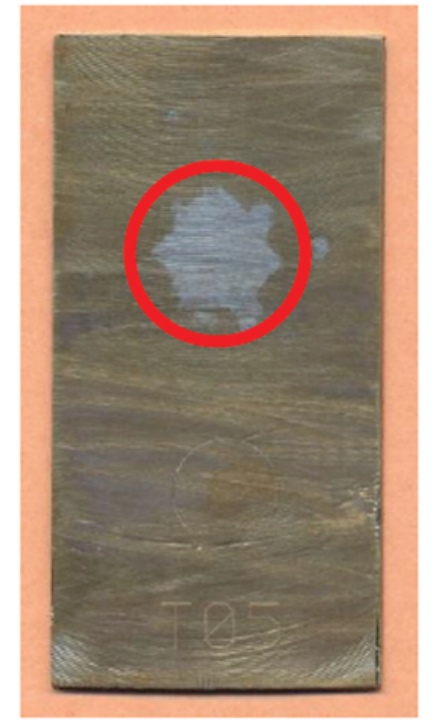

\section{Korozní úbytek : $<0.0005 \mathrm{~g}$}

Obr. 6. Vzorek po expozici varianta IV., teplota $265^{\circ} \mathrm{C}$ Fig. 6. Sample of 08Kh18N10T after the test IV, $265^{\circ} \mathrm{C}$

Po zkoušce korozní odolnosti při kontaktu povrchu materiálu s krystalickou $\mathrm{H}_{3} \mathrm{BO}_{3} \mathrm{v}$ prostředí s přítomností vodních par byl povrch bez taveniny kyseliny metaborité, patrná byla pouze stopa po původně př́tomné tavenině, překrytá částečně oxidickým filmem vzniklým až po odpaření $\mathrm{HBO}_{2}$.

$\mathrm{Na}$ vzorcích exponovaných při teplotě $297{ }^{\circ} \mathrm{C}$ při periodickém smáčení povrchu kovu roztokem kyseliny borité není patrné místo dopadu kapek korozního média, protože povrch vzorků byl před účinky kyseliny borité chráněn vznikem parního polštáře na rozhraní kapka - vzorek.

\section{DISKUSE}

Otevřený korozní systém obsahující vodné roztoky kyseliny borité za teplot nad bodem varu je značně komplikovaný především z důvodu schopnosti kyseliny borité přecházet ve značné míře do parní fáze. Tato skutečnost akcentuje vliv zvoleného konstrukčního řešení korozí ohrožené komponenty, zvláště co se týká možnosti odvětrávání uzavřených prostor a přítomnosti teplotního gradientu v korozním systému (ochranné kryty, tepelná izolace atd.).

Vlastní mechanismus korozního působení kyseliny borité není jednoznačně popsán, významný vliv 
má nepochybně schopnost taveniny rozpouštět jinak chemicky stabilní oxidy tvořící se na povrchu konstrukčních ocelí.

Agresivita vodného roztoku kyseliny borité v uzavřeném systému za podmínek, které byly testovány v první části experimentálních prací je velmi nízká. Ani v prŕpadě uhlíkové oceli $22 \mathrm{~K}$ a bainitické oceli 15Ch2MFA nepřesáhla korozní rychlost hodnotu $0,01 \mathrm{~mm} /$ rok a z hlediska konstrukčně-bezpečnostního je nevýznamná. Hodnoty korozních rychlostí, uvedené v Tabulce 1 je nutné i přes nízké absolutní hodnoty považovat za silně konzervativní, a to z důvodu krátké doby expozice. Oxidická vrstva vzniklá jako výsledek interakce mezi kovem a korozním roztokem má zvláště $\mathrm{v}$ př́padě korozivzdorné oceli 08Ch18N10T velmi dobrý ochranný účinek, který $\mathrm{v}$ experimentu nebylo možno z důvodu krátké expoziční doby zohlednit. Je vysoce pravděpodobné, že dlouhodobější expozice by se projevila dalším snížením korozní rychlosti především u korozivzdorné oceli. I na základě konzervativních výsledků experimentu lze konstatovat, že absolutní hodnoty korozních rychlostí jsou ve všech případech velmi nízké u obou testovaných korozních prostředí a z pohledu konstrukční bezpečnosti nepředstavují provozní riziko.

Při zkoušce periodického vlhčení povrchu metodou kapání korozního roztoku na definovaně ohřátý volný povrch zkoušeného materiálu se zásadním způsobem projevil vliv schopnosti kyseliny borité a metaborité přecházet s vodní párou do plynné fáze. Za zadavatelem definovaných podmínek hraje významnou úlohu chování kapalného korozního média při dotyku s povrchem vzorku. Při teplotě povrchu vyšší než cca $230{ }^{\circ} \mathrm{C}$ dojde před vlastním kontaktem kapky s povrchem ke tvorbě parního polštáře mezi povrchem vzorku a kapkou korozního média a korozní roztok se i s kyselinou boritou zcela odpaří bez korozních účinků na materiál. Při nižší teplotě (v testovaném prŕípadě $\mathrm{v}$ intervalu teplot cca $160{ }^{\circ} \mathrm{C}$ až $230{ }^{\circ} \mathrm{C}$ ) dojde při kontaktu korozního média $\mathrm{s}$ povrchem $\mathrm{k}$ jeho lokálnímu ochlazení a intenzivnímu odpařování roztoku na povrchu vedoucímu $\mathrm{k}$ silnému koroznímu poškození. V závislosti na teplotě povrchu a koncentraci kyseliny borité v korozním médiu dochází

Tab. 4. Korozní rychlosti pro uhlíkovou a bainitickou ocel po experimentu periodického vlhčení povrchu metodou kapání korozního roztoku / Comparison of corrosion rates for both temperatures and all materials

\begin{tabular}{|c|c|c|}
\hline \multirow{4}{*}{$\mathbf{1 6 0}^{\circ} \mathbf{C}$} & $22 \mathrm{~K}$ & $9,58 \mathrm{~mm} /$ rok \\
\cline { 2 - 3 } & 15Ch2MFA & $4,63 \mathrm{~mm} /$ rok \\
\cline { 2 - 3 } & 08Ch18N10T & bez poškození \\
\hline \multirow{3}{*}{$\mathbf{2 3 0}^{\circ} \mathbf{C}$} & 22K & $4,73 \mathrm{~mm} /$ rok \\
\cline { 2 - 3 } & 15Ch2MFA & $4,21 \mathrm{~mm} /$ rok \\
\cline { 2 - 3 } & 08Ch18N10T & bez poškození \\
\hline
\end{tabular}

ke krystalizaci kyseliny borité a tvorbě masivních úsad (při nižší teplotě a vysoké koncentraci kyseliny borité), nebo jsou prrítomny pouze korozní produkty a přebytečná kyselina boritá odejde s vodní parou (při vyšší teplotě a nižší koncentraci kyseliny borité). Korozní rychlost je v obou př́padech vysoká (Tab. 4).

Korozivzdorná austenitická ocel 08Ch18N10T nebyla za zvolených podmínek korozně poškozená.

$\mathrm{Na}$ základě dosažených výsledků lze s vysokou pravděpodobností předpokládat, že podmínky pro odpařování kyseliny borité se radikálně změní v př́ípadě, kdy bude volný povrch kovu stíněn např́klad ochrannými kryty nebo tepelnou izolací. Kondenzace vlhkosti a př́tomné kyseliny borité $\mathrm{v}$ objemu porézních tepelněizolačních materiálů $\mathrm{s}$ teplotním gradientem a s komplikovanou ventilací může vyvolat podmínky vhodné pro průběh korozních procesů i za teplot převyšujících $230{ }^{\circ} \mathrm{C}$.

Zkouška koroze na definovaně kontaminovaných volných površích $\left(10 \mathrm{mg} / \mathrm{cm}^{2}\right)$ při zvolených teplotách proběhla na všech vybraných materiálech. Byla testována kontaminace volných povrchů $\mathrm{v}$ suchém prostředí a $\mathrm{v}$ prostředí zvýšeného obsahu vodních par. $\mathrm{Na}$ žádném z exponovaných vzorků se nepodařilo prokázat jakékoli projevy koroze, a to jak hodnocením metalografickým, tak i gravimetrickým. Pro ověření výsledku byla provedena expozice materiálů s vysokým stupněm kontaminace (na povrchu bylo roztaveno $0.1 \mathrm{~g}$ krystalické $\mathrm{H}_{3} \mathrm{BO}_{3}$ ) v suchém a ve vlhkém prostředí. Po 150 hodinách expozice $\mathrm{v}$ suchém prostředí byla na povrchu vzorku vrstva transparentní taveniny kyseliny metaborité, po jejím odstranění nebylo kromě rozpuštění oxidické vrstvy zjištěno korozní napadení povrchu vzorků. Experiment $\mathrm{v}$ prostředí zvýšeného obsahu vodní páry také neprokázal prrítomnost koroze, došlo pouze $\mathrm{k}$ oddestilování kyseliny borité $\mathrm{s}$ vodní párou. Z experimentu je zřejmé, že kontaminace volného povrchu zbytkovou kyselinou boritou (např́iklad po asanaci úniku primárního média otěrem) nepředstavuje z korozního hlediska riziko.

\section{ZÁVĚR}

Na základě experimentálních zkoušek za daných podmínek lze konstatovat:

- Korozní rychlost materiálů 08Ch18N10T, 22K a $15 \mathrm{Ch} 2 \mathrm{MFA} v$ uzavřeném prostoru v prostředí vodného roztoku kyseliny borité o složení $14 \mathrm{~g} / \mathrm{kg} \mathrm{H}_{3} \mathrm{BO}_{3}$ a $5 \mathrm{~g} / \mathrm{kg} \mathrm{H}_{3} \mathrm{BO}_{3}+\mathrm{KOH}$ na $\mathrm{pH}_{(300)} 7.2$ a při teplotě $297^{\circ} \mathrm{C}$ se pohybuje v řádu jednotek mikrometrů za rok a z konstrukčního a provozního hlediska nepředstavuje bezpečnostní riziko.

- Koroze materiálu 08Ch18N10T nebyla prokázána v žádném z experimentů periodického vlhčení povrchu 
metodou kapání korozního roztoku na definovaně ohřátý povrch oceli a materiál lze za použitých zkušebních podmínek považovat za rezistentní.

- Pro uhlíkovou ocel $22 \mathrm{~K}$ a bainitickou ocel 15Ch2MFA bylo během experimentu periodického vlhčení povrchu metodou kapání korozního roztoku prokázáno výrazné korozní napadení při teplotách povrchu $160{ }^{\circ} \mathrm{C}$ a $230{ }^{\circ} \mathrm{C}$, a to rádově v jednotkách $\mathrm{mm}$ za rok. Stejná zkouška při teplotě $265{ }^{\circ} \mathrm{C}$ a $297^{\circ} \mathrm{C}$ neprokázala korozní napadení z důvodu vzniku parního polštáře jako bariéry pro korozní procesy.

- Zkouška korozní rychlosti při kontaminaci povrchu ocelí kyselinou boritou v plošné koncentraci $10 \mu \mathrm{g}$ na centimetr čtvereční neprokázala při žádné ze zvolených teplot korozní napadení některé z testovaných ocelí, a to jak v suché, tak i vlhké atmosféře.

- Zkouška masivní kontaminace povrchu ocelí krystalickou kyselinou boritou $\left(0.1 \mathrm{~g} \mathrm{H}_{3} \mathrm{BO}_{3}\right.$ na ploše cca $1 \mathrm{~cm}^{2}$ ) vedoucí $\mathrm{k}$ tvorbě souvislé vrstvy taveniny kyseliny metaborité neprokázala při žádné ze zvolených teplot průběh korozních procesů ani v suché, ani ve vlhké okolní atmosfére.

\section{LITERATURA}

1. Boric Acid Corrosion Evaluation (BACE) program phase L-Task 1 report: Industry experience reference and available test data summary, 1993.

2. Timofeev B.: Assessment of the first generation RPV state after designed lifetime. International Journal of Pressure Vessels and Piping 2004, 81, 703-712.

3. Jursík F.: Anorganická chemie nekovů. VŠCHT Praha, 2001.

4. Klikorka J., Hájek B., Votinský J.: Obecná a anorganická chemie. SNTL: Praha, 1989.

5. Kocakusak S., Köroglu H.J., Tolun R.: Drying of wet boric acid by microwave heating. Chemical Engineering and Processing 1998, 37, 197-201.

6. Kukuljan J.A., Alvarez J.L., Fernández-Prini R.: Distribution of $\mathrm{B}(\mathrm{OH})_{3}$ between water and steam at high temperatures. The Journal of Chemical Thermodynamics 1999, 31, 1511-1521. 